\title{
Psychosemantic Approach as the Basis of Algorithmization of Students' Work with Vocation- Oriented Information
}

\section{El enfoque psicosemántico como la base de la tecnología para algorítmizar el trabajo de los estudiantes con información textual de un plan profesionalmente orientado}

\section{Bystrenina Irina}

Russian State Agrarian University - Moscow Timiryazev Agricultural Academy, Moscow, Russian Federation

ORCID: https://orcid.org/0000-0001-5424-691X

\section{Tsupikova Elena}

Siberian State Automobile and Highway Academy, Omsk, Russian Federation ORCID: https://orcid.org/0000-0002-7849-4843

\section{Pogukaeva Anna*(i)}

Peoples' Friendship University of Russia (RUDN University), Moscow, Russian Federation ORCID: https://orcid.org/0000-0002-1309-9754

Tsibizova Oksana

Russian State Agrarian University - Moscow Timiryazev Agricultural Academy, Moscow, Russian Federation ORCID: https://orcid.org/0000-0003-0674-7140

*Correspondencia

Email: PogukaevaAnna@gmail.com
Citar como:

Bystrenina, I., Tsupikova, E., Pogukaeva, A., Tsibizova, O. \& (2021). Psychosemantic Approach as the Basis of Algorithmization of Students' Work with VocationOriented Information, 9(SPE2), e1022. Doi: http://dx.doi.org/10.20511/pyr2021.v9nSPE2.1022 


\section{Summary}

The article substantiates the need to create a technology for algorithmic work with professionally oriented information of a textual nature, based on the principles of the psychosemantic approach, which make it possible to most effectively define and logically form the semantic components of external speech and thinking. The authors of the article apply the original methodological concept of the characteristics of textual information, which is considered as a mechanism of learning and professional communication. Algorithmization of the process of mastering information will speed up the learning process and master a large amount of complex professional information. The algorithms proposed in the described technology have the property of modifiability and can be applied by students in their further studies and professional activities in a wide range of information interaction situations.

Keywords: Psychosemantic approach, algorithmization, information, text, professional communication.

\section{Resumen}

El artículo justifica la necesidad de crear una tecnología de algorítmica para trabajar con información textual orientada profesionalmente basada en los principios del enfoque psicosemántico, lo que permite determinar de manera más efectiva y diseñar lógicamente los componentes semánticos del habla y el pensamiento externos. Los autores del artículo aplican el concepto metódico original de las características de la información textual, que se considera como un mecanismo para la cognición y la comunicación profesional. La algorítmización en el proceso de asimilación de la información acelerará el proceso de educación y dominará una gran cantidad de información profesional compleja. Los algoritmos ofrecidos en la tecnología descrita tienen la propiedad de modificabilidad y pueden ser aplicados por los estudiantes durante las actividades académicas y profesionales adicionales en una amplia gama de situaciones de interacción informativa.

Palabras clave: Enfoque psicosemántico, algorítmica, información, texto, comunicación profesional.

\section{Introduction}

The ability to enhance their professional level themselves and willingness for selfdevelopment and self-education are often called the main qualities of a modern professional. Such an activity requires specific intellectual and psychological mobility, willingness to get and process huge amount of new compound information, as well as the ability to correct, expand, and restructure one's own experience and activity.

The skill of working with information is not spontaneous, being the result of students' targeted learning how to organize their activity, i.e. how to set goals, identify their stages, model process of achieving, plan and follow work process, and give its results an objective assessment.

\section{Problem statement}

Based on such modern tendencies as rapidly expanding and more complex scientific data, university didactics follows the path of optimizing educational activity, especially algorithmization of students' activity which intensifies their thought processes (and, therefore, 
provides higher results in education activity), avoiding any possible overstrain (i.e. with minimum time and effort required).

The current situation in the field of education presupposes optimization with mandatory forming and improving students' skills of work with information which requires thorough consideration of psychological and pedagogical conditions for introducing innovations into the educational process at university.

The higher education system, however, has certain contradictions which considerably complicate students' acquiring necessary skills and abilities, as well as optimization of their learning itself. They include:

- the need for quick and reliable comprehension of vast amounts of information, with no effective algorithms for such an activity;

- self-improvement of thinking required from students, with spontaneous character of organizing their intellectual development and self-reflection;

- the demand for students' integral and systematic idea of text structure and concept, the stages of its comprehension and structuring, with students' fragmented knowledge in the field of semantics of linguistic and verbal units;

- the focus on students' shift from education to self-education, with little skill of selfreflection and knowledge about the mechanism of thought and speech processes in communication and cognition.

Our research topic reflects the need for improving the system of selection and organization of work with vocation-oriented information from the point of psychosemantic approach.

The concept, hence, is relevant due to the following factors:

- the tendency to integrate theories from different scientific areas to solve interdisciplinary problems;

- the last achievements of interdisciplinary fields of science (psycholinguistics, psychosemantics, cognitive linguistics, information theory, etc.), concerning the algorithms od processing textual information, including vocation-oriented data;

- the last achievements of semasiology in interpretation and reasoning of communicative and cognitive aspects of students' verbal and intellectual activity;

- the last achievements of language education in organizing proper comprehension and effective transfer of textual information;

- the last achievements of psychology and pedagogics in restructuring educational process to help students shift to self-education and support developed self-reflection;

- the need to develop and introduce reliable comprehension algorithms (transmission of information into knowledge) and text reproduction algorithms (transmission of knowledge into textual information);

- the need to develop students' speech (both external and inner ones), which indicates the level of their thought.

The article aims to explain the usefulness of psychosemantic approach in organizing students' work with vocation-oriented information.

\section{Research approaches and methodology:}

- the systematic approach to the subject and object of the research, which allowed to identify a cluster of factors and conditions, necessary for creating a science-based technique of algorithmization of technical university students' work with vocation-oriented information;

- conceptual method of identifying the level of correlations of the contents, educational paradigms and techniques with technical university students' specifics of psychophysical development, along with their communicative and cognitive needs;

- comprehensive theoretical analysis of the object:

- generalization od data from different aspects of linguistics, language education, pedagogics, and psychology in order to integrate them in the interdisciplinary phenomenon of students' cognitive and informational activity; 
- development of a language educational model of algorithmization and its components (contents and objective, organization and activity, control and assessment);

- survey and diagnostics: testing; questionnaire survey.

\section{Discussion}

Students' shift from education to self-education is considered the key objective of modern education. Such an objective is caused by the need to process vast amounts of learning material with learning time limited with educational programs and students' inability to perform 24-hour educational activity. Thus, educational process should be restructured in a way which would significantly improve students' comprehending and memorizing vocation-oriented information.

Starting with L.S. Vygotsky, many scholars and pedagogues assert a close link and even integrity of speech and thought development, and, hence, highlight the need to determine educational content in a way which would accelerate and improve students' speech and thought processes.

Algorithmization of comprehending vocation-oriented texts, based on psychosemantic approach, provides:

- building an educational process on the basis of the following principles: semantical (the principle of related logical and linguistic categories, the principle of analyzing text from the point of external and inner speech, the principle of differentiating meaning and message (semantics of external speech and semantics of thought correspondently); the principle of identifying semantic links among pieces of information (conceptual understanding) in order to comprehend information and transfer knowledge into long-term memory; psychopedagogical (the principle of self-reflection following education activity; the principle of finding motivation by determining the usefulness and applicability of information; the principle of recursive presentation of learning material; the principle of concentration in presentation of learning material) and psycholinguistic (the principle of mutual shift from inner speech to external one and vice versa, the principle of building of logical frameworks; the principle of conceptual estimating quantity and quality of information);

- using terms from different sciences which study information, communication and human psyche, in the formation of term base of the course.

The modern methodology of teaching linguistic subjects states the idea of polyphonic approaches to teaching, which means the need to select complementary components from different approaches, providing accordance between innovations proposed and psychopedagogical conditions at university, and to explain the choice.

The components of text-oriented approach are implemented in the algorithm of comprehending textual information; psycholinguistic approach which study the stages and processes of understanding text structure and message, is used in the algorithm of identifying presuppositions. We took the components of informative approach into consideration when developing algorithms of identifying text completeness and its qualities. We took into account semasiological approach when developing the plan of analyzing linguistic and verbal units of the text, as well as the variants of design forms, with differentiated notions of meaning and message of units in external and inner speech.

In our opinion, psychosemantic approach is the leading approach to organizing algorithmization of students' speech and thought activity when comprehending vocation-oriented texts.

The main theses of psychosemantics one should take into account when teaching a language are based on the concept of constructivism, according to which an individual's system of knowledge includes numerous opinions, beliefs, and reactions, caused by their own life experience in interacting with the world and others, rather than mirrors the world. The opportunity of communication with other people forms a cognitive mechanism called self-communication: The dialog begins with the consciousness (Bakhtin, 1995). The dialog doubles the world, but it is not the only way to do it: "World doubling is the main advantage of a person with language skills. With the language which denotes objects, they can deal with the objects which one cannot 
perceive directly and experience... An individual has a doubled world consisting of the reflected objects and ideas, objects, relations and qualities defined by words. In a nutshell, a word is a specific form of reflecting the reality. A person may call these ideas arbitrarily, whether they exist or not...and rule this second world arbitrarily as well" (Luria, 1979, p. 37).

As A.N. Leontyev (1999) points out, each word is the sum of people's social activity fixed in its meaning. Thanks to it, an individual is able to use experience of other people and their ancestors. Grammatical structures, isomorphic to activity structures, allow a person to do a thought experiment when acquiring knowledge. That is, the meaning of the word is a generalized ideal model of the object in an individual's mind. The model contains substantial qualities of the object and the ways to interact with it. In this connection, one should remember the expanded interpretation of the language as the sum of words, ritual gestures, actions, and visual symbols (Zhinkin, 1982; Miller, 1964). The main issues of psychosemantics are interrelations of the language, speech and thought, as well as categories of meaning and message. The psychosemantic approach considers the processes of cognition and communication as a systematic work of psychic mechanism based on defining the message (semantics) of the objects in reality.

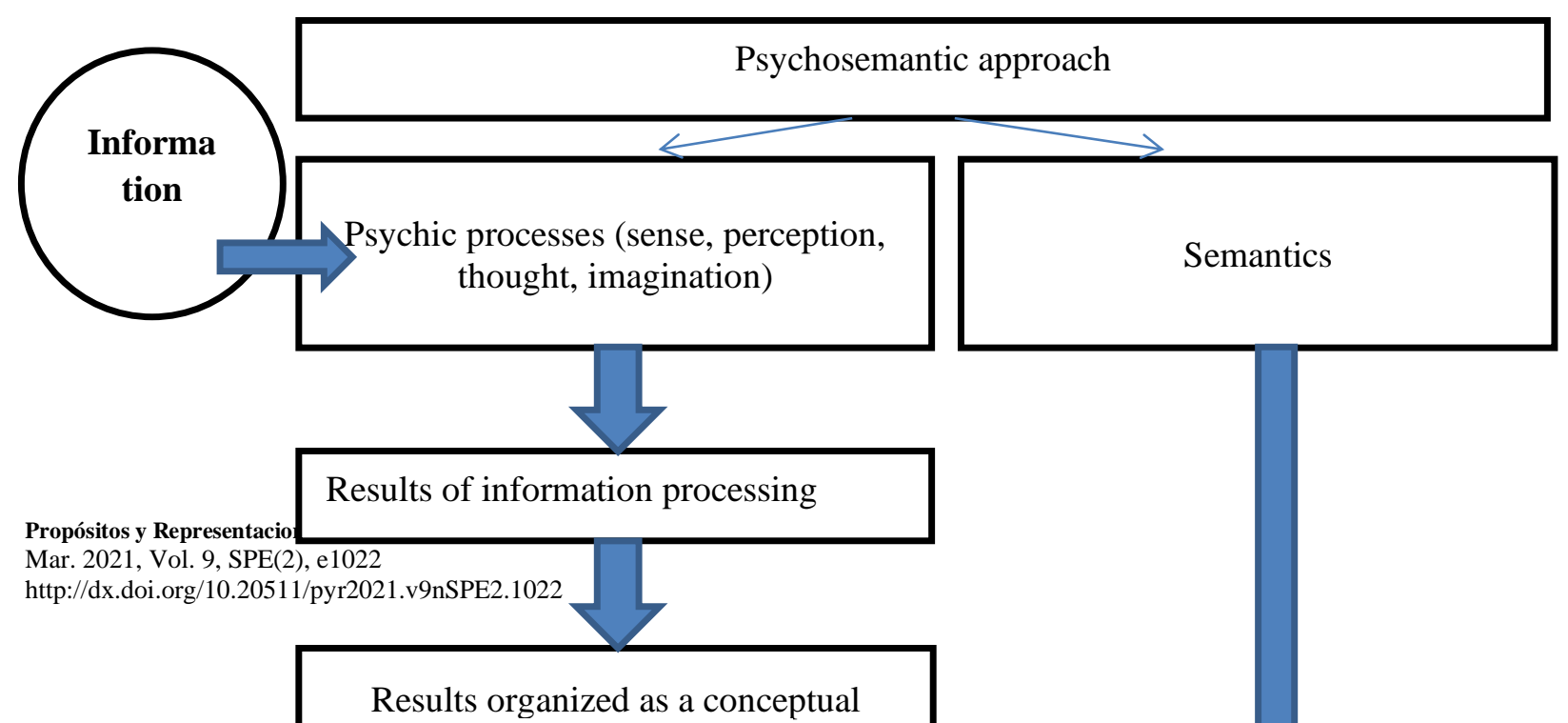




\section{Scheme 1. Psychosemantic approach}

Consider the table. Information about external world is perceived and analyzed with organs of sense. The results of such an analysis form conceptual paradigms, combined into universal and objective codes and then into conceptual framework - knowledge. Knowledge (experience) is stored in the long-term memory and can be extracted if necessary. Knowledge is processed in a person's mind with the system of operation and linguistic units. Intellectual processing of experience and information results in structuring in the inner speech with message. It is expressed in texts and their thematic networks which are the units of external speech with certain meaning and message. Meaning and message of linguistic and verbal units (including inner speech) can be called semantics. Therefore, the psychosemantic approach considers an individual interaction with the reality from external world information to knowledge (its inner idea) and then to the transmission of knowledge into text (subsequent stages of interiorization and exteriorization).

Based on the abovementioned, highlight and describe semantic, psychopedagogical and psycholinguistic principles of psychosemantic approach in language education methodology, especially in the work with vocation-oriented and scientific texts.

The principles of algorithmization of students' work with vocation-oriented information based on psychosemantic approach

Dealing with algorithmization and optimization of educational process requires paying special attention to methodological basics professors and methodologists could rely on. A correct selection of teaching principles, corresponding to educational goals and objectives (in this case, algorithmization of work with textual information in the terms of interiorization and exteriorization) is a necessary condition for achieving the result.

Teaching principles are to structure educational process in the terms of cognition in general, they reflect the key patterns of educational process: the principle of visualization (reliance on life experience and influence on students' organs of sense); the principle of consciousness and activity 
(formation of students' self-independence and motivation based on conscious transmission of information into thought framework); the principle of intelligibility (definition of learning context with regard to students' individual specifics including their professional interests); the principle of high-level learning (activation of students' cognitive interest through educational problems, heuristic algorithms and other educational means); the principle of scientific development (logical organization and selection of learning material, based on the most valuable scientific progress); the principle of individual approach (giving students tasks of different difficulty level to enhance students' inner algorithms); the principle of systematicity and consistency (following logical sequences and cross-curriculum relations); the principle of solidity in acquiring KSA's (organization of training mnemonic algorithms); principle of theory-practice interrelation (organization of work aimed at generalizing learning material, defining its links to a broad context of professional activity).

Algorithmization demands defining the relations between educational and learning principles and certain theses of information theory. Present them in a tabular form:

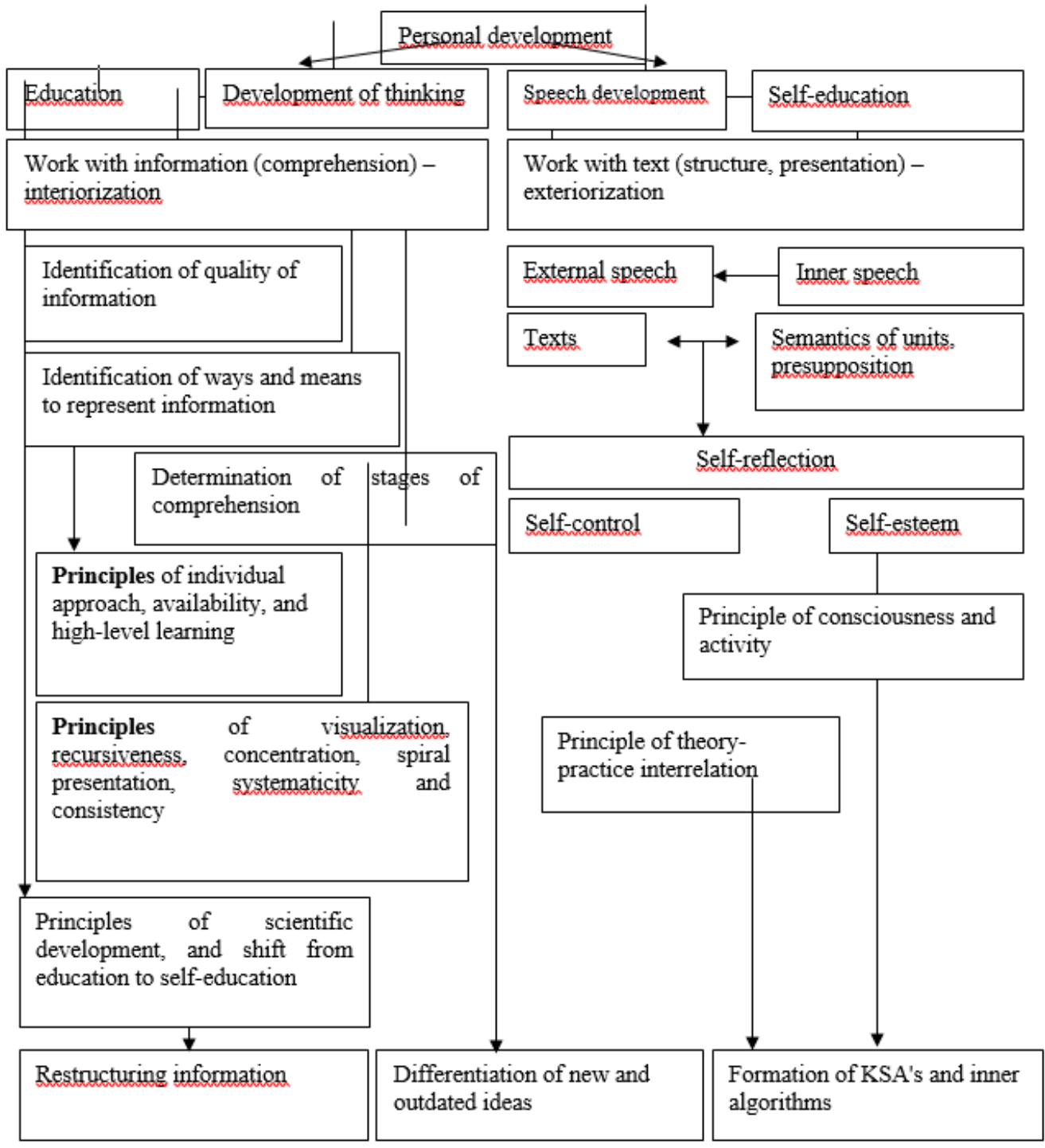

\section{Scheme 2. Relation between learning principles and theses of information theory}

To sum up, the technique can be briefly described in the following way: 
Algorithmization of comprehending vocation-oriented information, based on psychosemantic approach as the psychopedagogical basis of the research relies on interiorization theory, speech and thought theory, G.A. Miller's (1964) working memory capacity theory, the theory of differentiating information and knowledge, and academic papers of Russian and foreign researchers on issues of students' learning and intellectual development. As the main teaching method, a text-visual aids scheme is used, i.e. a combination of textual and visual means of presentation.

The technique is to provide transforming information into knowledge (interiorization) which is to be transformed into a logical and substantial text (exteriorization). Each stage of the technique is followed by a specific algorithm.

Within algorithmization of work with textual information the process of learning forms the skill of processing information and transforming it into knowledge which can be applied if necessary, with an interim stage of identifying characteristics of information. This approach forms general skills of work with textual information: searching, identifying characteristics of information, structuring information, defining presuppositions, etc. The result is conscious-based inner motivation to study. The approach forms a skill of defining and extracting presuppositions from long-term memory by performing logical operations with concepts.

The core objective is to form a skill of self-independent searching, assessing, processing and using information; to form a self-sufficient subject of communication, able to work effectively with information flows during interiorization and exteriorization.

A student's own knowledge may only be the result of active intellectual activity rather than storing memorized data.

The described technique is based on person-oriented training and communicative method, which presuppose subject-object relationship between a student and a professor during educational process. The latter's function is, mostly, to coordinate and organize.

Objective assessing and processing obtained information undergo a certain algorithm, based on human speech and thought mechanism, and provide effective development of logical, figurative, creative, reflexive and other kinds of thought.

Being an informative cognitive fact and the main learning unit, the text should be analyzed and assessed. Its clear reflexive structure and visual reasoning of interrelations among the concepts make students more inventive and creative.

The method of problem presentation of new learning material is used to demonstrate the principles and stages of transforming information into knowledge.

Cognitive motivation grows from certain expectations concerning the results of education such as: development of different types of thinking, thought operations, self-reflection, memory, attention, imagination, and perception. The technique is aimed at developing different kinds of thought, imagination, memory and self-reflection. A student forms their new knowledge themselves; a student's ability to freely present the learning material orally with the help of visual aids indicates their level of knowledge (understanding, memorizing).

The suggested technique is reasoned with science-based patterns of thinking during the acquisition of knowledge: processing information during its denotate-predicative analysis presupposes clear differentiation of meaning and message; therefore, it presupposes destruction of perception stereotypes and prevention from taking unchecked information on faith. Training students to clearly organize the semantic structure of their speech presupposes the ability to express the message as precisely as possible. The scheme of transforming information into knowledge is supported with combined visual aids and verbal means.

The training is based on educational principles of scientific development, intelligibility, recursiveness, concentration, etc.

The structure of the pedagogical technique includes two ways of work: exteriorization of thought framework (converting inner ideas into external speech, textual information) and interiorization (converting information into own applicable knowledge). Each aspect of the work has its own stages, which correspond to algorithm steps.

The organizational forms of the technique are practical knowledge and problem-raising lecture.

To summarize, algorithmization consists of the following components: 
1) Motivation and goal. The professor is to:

- use modern educational technologies in their effective combinations determined by specific conditions of education;

- develop students' skills and abilities to work effectively with textual vocation-oriented information;

- form and improve students' skills of performing universal educational tasks in the terms of cognitive and communicative information;

- set the educational goal and identify the stages of achieving;

- create the atmosphere which would help students' form the system of knowledge in the specific field;

- increase students' interest in study and the subject in an entertaining and exciting form.

2) Contents presuppose scientific data of text linguistics, semasiology, psycholinguistics, information theory, which provide students with a comprehensive idea of text processing algorithm and, thus, algorithmization itself.

3). Means textual vocation-oriented information includes a combination of approaches, methods, ways, means, and forms of training.

From the point of psycholinguistic approach we create an algorithm of processing textual information with stages of interiorization and exteriorization, which presupposes using such methodology as text reconstruction, transformation, compression and unfolding.

From the point of text-centric approach the text becomes the main cognitive and communicative unit, being the main educational unit as well; its structure consists of external and internal levels in invariant-variant relations.

In a nutshell, the substantial innovations of our technique are:

- developing and introducing an algorithm of processing textual information created according to speech and thought theory;

- making correlations of linguistic, mental and logical categories;

- organizing the processes of interiorization of information and exteriorization of the enriched message into the text;

- optimizing students' work, thought, memory, attention by means of text and visual aids used simultaneously.

\section{Organization.}

The forms and methods of organizing students' educational activity presuppose their active role in it. The objective of algorithmization can be achieved only in the conditions of developing education, which includes:

- demonstrating the importance, usefulness and applicability of obtained information, defining the fields where algorithms can be applied, highlighting advantages of an activity optimized with the help of algorithmization;

- helping students to form an integral conceptual framework, identify interrelations among concepts, and to store information successfully in order to transmit it into the long-term memory, as well as to find quick methods of remembering necessary information;

- creating didactic problems by asking problematic questions and demanding creative solutions and answers;

- developing the skill of self-reflection by asking students to find the right algorithm for an interpretative situation. The issues of algorithmization and work optimization make students think of logical, communicative and psychological matters. 5. Reflection and assessment allow evaluating the effectiveness of the technique. Students' self-reflection is formed with self-control and self-esteem algorithm also including students' answers to the following questions and completing the sentences below:

What am I doing and what for?

What should I know to do the task?

What situations require the skill and the results of doing similar tasks?

How do the results correspond to my expectations before the task has been done?

The information may help me...

It was interesting for me to learn that..., because...

Today I've understood.... And I've also specified... 
I've learned...

\section{Conclusion}

To summarize, the article:

- explains and proves the need for algorithmization of work with textual vocation-oriented information with the help of psychosemantic approach which allow to effectively identify and logically express the contents of external speech and thought;

- uses the original methodological concept of text characteristics, considered as the cognitive mechanism of professional communication;

- develops students' thought development concept with regard to structural patterns of speech and thought processes: students' thought development requires algorithm of interiorization and exteriorization through the stage of inner speech, along with algorithm of identifying presuppositions, with the help of mental operations and basic conceptual components of information;

- devises methodology focused on interiorization and exteriorization: creating a new text based on two or more ready texts and metonymic word pairs; synthesis; logical structuring of information; enriching text informativeness; correcting text roughness; analysis; association; text compression; creating and comparing variants of presentation; identifying presuppositions, etc.;

- defines and describes the indicators of students' effective thought development (the ability to make a logical scheme of the text, reconstruct presupposition; to present the text with explanatory notes; to present variants of the text with different level of informational completeness).

\section{Referencias}

Bakhtin, M.M. (1995) Human in the world of speech [Bakhtin M.M. Chelovek v mire slova]. Russian Open University, 139, Moscow, Russia.

Leontyev, A.N. (1999) Activity and Personality. Personal Psychology, Vol. 2, Anthology [Leontyev, A.N. Deyatel'nost' i lichnost' // Psikhologiya lichnosti. T.2. Khrestomatiya]. Samara, Russia.

Luria, A.R. (1979) Language and Cognition [Luria, A.R. Yazyk i soznanie], 319, Moscow, Russia.

Miller, G.A. (1964) The Magical Number Seven, Plus or Minus Two. Psychological Review, 1956. [Rus.: Miller Dzh. Magicheskoe chislo sem' pl'us ili minus dva. Engineering psychology, 192-225, Moscow, Russia.

Nikitin, P., Gorokhova, R., Bazhenov, R., Bystrenina, I. (2020). Applied orientation and interdisciplinary integration as a factor in increasing student learning motivation [Nikitin, $P$., Gorokhova, R., Bazhenov, R., Bystrenina, I. (2020) Prikladnaya napravlennost' $i$ mezhdisciplinarnaya integraciya kak faktor povysheniya uchebnoj motivacii studentov]. Universal Journal of Educational Research, 8(10), 4931-4938

Nikitin, P.V., Bazhenov, R., Bystrenina, I., Zueva, T., Fominykh, I. (2018). Modern approaches to teaching programming [Nikitin, P.V., Bazhenov, R., Bystrenina, I., Zueva, T., Fominykh, I. (2018) Sovremennye podhody $k$ obucheniyu programmirovaniyu]. Proceedings of the 32nd International Business Information Management Association Conference, IBIMA 2018 - Vision 2020: Sustainable Economic Development and Application of Innovation Management from Regional expansion to Global Growth, 7832-7836

Petrenko, V.F. (2005) The basics of psychosemantics [Petrenko V.F. Osnovy psikhosemantiki], 4-12, Saint Petersburg, Russia.

Rubinstein, S.L. (2003) The Basics of General Psychology. [Rubinstein, S.L. Osnovy obshchey psikhologii], 713, Saint Petersburg, Russia

Tsupikova, E.V. (2016) Semantic structure of texts in the technique of intensifying students' speech and thought development and optimizing educational process by means 
of linguistic scientific and methodological material [Tsupikova, E.V. Semanticheskaya struktura teksta $\mathrm{v}$ tekhnologii intensifikatsii razvitiya rechi i myshleniya studentov $\mathrm{i}$ optimizatsii uchebnogo protsessa sredstvami lingvistiki nauchnykh i uchebnometodicheskikh statey], 57-66., Moscow, Russia.

Zhinkin, N.I. (1982) Speech as a Conduit for Information. [Zhinkin, N.I Rech kak provodnik informatsii], 159, Moscow, Russia.

* This paper has been support by the RUDN University Strategic Academic Leadership Program. 